\title{
Universiteit
}

Leiden

The Netherlands

\section{Imperial Germany and the Herero of Southern Africa: genocide and the quest of recompense}

Gewald, J.B.; Jones A.

\section{Citation}

Gewald, J. B. (2004). Imperial Germany and the Herero of Southern Africa: genocide and the quest of recompense. In Genocide, war crimes and the West: history and complicity (pp. 59-77). London: Zed Books. Retrieved from https://hdl.handle.net/1887/4853

Version: $\quad$ Not Applicable (or Unknown)

License: $\quad$ Leiden University Non-exclusive license

Downloaded from: https://hdl.handle.net/1887/4853

Note: To cite this publication please use the final published version (if applicable). 
Imperial Germany and the Herero of

Southern Africa: Genocide and

the Quest for Recompense

Jan-Bart Gewald

On 9 September 2001, the Herero People's Reparations Corporation lodged a claim in a civil court in the US District of Columbia. The claim was directed against the Federal Republic of Germany, in the person of the German foreign minister, Joschka Fischer, for crimes against humanity, slavery, forced labor, violations of international law, and genocide.

Ninety-seven years earlier, on II January 1904, in a small and dusty town in central Namibia, the first genocide of the twentieth century began with the eruption of the Herero-German war. ${ }^{1}$ By the time hostilities ended, the majority of the Herero had been killed, driven off their land, robbed of their cattle, and banished to near-certain death in the sandy wastes of the Omaheke desert. The survivors, mostly women and children, were incarcerated in concentration camps and put to work as forced laborers (Gewald, I995; 1999: I4I-9I). Throughout the twentieth century, Herero survivors and their descendants have struggled to gain recognition and compensation for the crime committed against them.

Following a brief description of the Herero genocide, this chapter provides a chronological overview of the way in which the Herero have sought to draw the world's attention to the crimes committed by Imperial Germany in Namibia. Calls for compensation will in the end revolve around the issue of German government responsibility. That is, to what extent were the Herero genocide and related atrocities the product of official German policy? To what extent were the criminal acts not merely the actions of individuals? Material presented here will show that the Herero genocide and associated atrocities were indeed officially sanctioned In the war, the German settlers and soldiers carried out a shoot-to-kill 
policy, conducted extrajudicial killings, established concentration camps, employed forced labor, and in at least two cases established death camps. After the war, the loss of Herero liberty, land, and stock was officially sanctioned in legislation. At no stage after 1904 were any German settlers or soldiers brought to justice for genocidal acts committed in Namibia between 1904 and 1908 .

\section{The Herero-German War}

In 1904 , a war characterized by extreme brutality and deliberate genocide broke out in the central Namibian settlement of Okahandja. It arose from a series of misunderstandings and the self-fulfilling prophecies of the paranoid settler class. ${ }^{2}$ As the war steadily spread across central Namibia, it grew in intensity and viciousness, as fresh contingents of German troops despatched from Imperial Germany poured into the country and attempted to impose their vision of 'order' on the territory and its inhabitants. The personal involvement of the German Kaiser, Wilhelm II, in deciding how the war was to be fought in German South West Africa signalled the highest authorization and endorsement for acts committed in the name of Imperial Germany. In a conscious policy of genocide, German soldiers and settlers sought, shot, beat, hanged, starved, and raped Herero men, women, and children. When the war finally ended, no fewer than 80 per cent of the Herero had lost their lives. Those who remained in Namibia, primarily women and children, survived in concentration camps as forced laborers employed on state, military, and civilian projects (Gewald, 1999: I4I-230). In short, the war and its aftermath were characterized by extreme acts of violence and cruelty on the part of German soldiers and settlers.

The diaries, letters, and photographs of contemporaries graphically portray the indiscriminate shootings, hangings, and beatings which were the order of the day. Missionary Elger, stationed in the settlement of Karibib, described the manner in which Herero prisoners were treated:

Things proceeded in a particularly brutal manner. Herero prisoners were terribly maltreated, whether they were guilty or not guilty. About 4 Herero were taken prisoner, because they were supposed to have killed a railway worker (Lehmann, Habis). The court martial ordered them to be freed and declared them to be not guilty. However one could not relesse them as they bore too example, people had beaten an eye out of one. After the court martial had declared them to be innocent, some of the Germans outside immediately resumed the abuse with the words, 'the court has declared you to be innocent, we however want to string you up."
After the initial battles, the civilian governor was relieved of his command and replaced by the Kaiser's own candidate, Lieutenant-General Lothar von Trotha. ${ }^{4}$ Under the command of von Trotha, the German army sought to engineer a crushing defeat of the Herero in the vicinity of the Waterberg (Pool, I979: 210-II). In keeping with von Moltke's principles of separate deployment and encirclement, von Trotha sent his armies to annihilate the Herero at the Waterberg. Or, as he put it in his own words:

My initial plan for the operation, which I always adhered to, was to encircle the masses of Hereros at Waterberg, and to annihilate these masses with a simultaneous blow, then to establish various stations to hunt down and disarm the splinter groups who escaped, later to lay hands on the captains by putting prize money on their heads and finally to sentence them to death. (von Trotha's diaries cited in Pool, 1991: 25I)

On I I August, the battle of Hamakari at the Waterberg took place. The Herero were defeated and fled in a southeasterly direction into the dry desert sands of the Kalahari, known to the Herero as the Omaheke. ${ }^{5}$ On Sunday, 2 October 1904, after holding a field service, General von Trotha addressed his officers (Rust, I905: 384). He declared that the war against the Herero would be pursued in all earnestness, and read a proclamation that stated, among other things:

The Herero people must ... leave the land. If the populace does not do this will force them with the Groot Rohr [cannon]. Within the German borders every Herero, with or without a gun, with or without cattle, will be shot. I will no longer accept women and children, I will drive them back to their people or I will let them be shot at.

These are my words to the Herero people.

[Signed] The great General of the mighty German Kaiser. ${ }^{6}$

A number of authors have sought to deny or at least downplay the existence and implications of Trotha's proclamation, which has become known as the extermination order (Vernichtungsbefehl). ${ }^{7}$ However, Trotha's own words, in his diary and elsewhere, indicate that he understood the implications of his proclamation full well. On the day the proclamation was issued, Trotha wrote in a letter:

I believe that the nation as such should be annihilated, or, if this was not possible by tactical measures, have to be expelled from the country by operative means and further detailed treatment. This will be possible if the water-holes from Grootfontein to Gobabis are occupied. The constant movement of our troops will enable us to find the small groups of the nation who have moved back westwards and destroy them gradually. 
My intimate knowledge of many central African tribes (Bantu and others) has everywhere convinced me of the necessity that the Negro does not respect treaties but only brute force. (Pool, I991: 272-4)

From 1904 and into I905, one of von Trotha's officers, Major von Estorff, 'had the thankless task of chasing after the refugees in the Sandveld and preventing their return'. Estorff's own words clearly describe both his own actions and the intentions of his commanding officer, Trotha:

I followed their spoor and found numerous wells which presented a terrifying sight. Cattle which had died of thirst lay scattered around the wells. These cattle had reached the wells but there had not been enough time to water them. The Herero fled ahead of us into the Sandveld. Again and again this terrible scene kept repeating itself. With feverish energy the men had worked at opening the wells; however the water became ever sparser, and wells ever at opening the fled from one well to the next and lost virtually all their cattle rare. They number of their people. The people shrank into small remeir cattle and a large ally fell into our hands [unsere Gewalt kamen]; small remnants who continunow and later through the Sandveld intomen]; sections of the people escaped swana]. It was a policy as gruesome into English territory [present-day Botso much. we a policy as gruesome as it was senseless, to hammer the people so much; we could have still saved many of them and their rich herds, if we had pardoned and taken them up again; they had been punished herds, if we had gested this to General von Trotha, but he wanted punished enough. I sug(von Estorff, 1979: II7; author's translation)

In early I905, the German parliament rescinded von Trotha's extermination order, after which time captured Herero were placed into concentration camps (Konzentrationslager) and put to work as forced laborers. B late I905, an estimated 8,800 Herero were confined in camps, working on various military and civilian projects scattered across German South West Africa (Berichte der Rheinischen Missions-Gesellschaft, German South Wes sources provide us with eyewitness accountlschaft, I906: 10). Missionary Missionaries stationed in the Herero camps. superiors in Gerero Konzentrationslager reported to their superiors in Germany on the extensive and unchecked rape, beatings and execution of surrendered Herero by German soldiers (Gewald, I999: I $84-$ 204). Missionary Kuhlmann spoke of the delight of settler women witnessing the drawn-out public hangings of captured Herero in Windhoek At one such hanging, a drooling Herero fighting for his life was berated: 'You swine, wipe your muzzle' (Oermann, I998: missionary Elger wrote: And then the scattered Herero returned from the Sandfeld. Everywhere they
popped up - not in their original areas - to submit themselves as prents. What did the wretched people look like?! Some of themselves as prisoners. skeletons with hollow eyes, powerless and home of them had been starved to particularly with dysentery. In the settlements they were placed in big kraals, and there they lay, without blankets and some without clothing, in the tropical rain on the marshlike ground. Here death reaped a harvest! Those who had rain on the marshlike ground. Here death reaped
some semblance of energy naturally had to work...

It was a terrible misery with the people; they died in droves. Once 24 came together, some of them carried. In the next hour one died, in the evening the second, in the first week a total of ten - all [lost] to dysentery - the people had lost all their energy and all their will to live...

Hardly cheering cases were those where people were handed in to be healed from the effects of extreme mistreatment [schwerer Misshandlungen]: there were bad cases amongst these. ${ }^{8}$

In the settlement of Windhoek, missionary Meier described the condition of Herero who came to the sickbay run by the mission. His words provide some idea of what occurred in the Windhoek camp:

How often these poorest, those who deserved pity, came staggering! Many of them, who could no longer move, were brought on stretchers, most of them unconscious; however, those who could still think were glad that the hard supervision of the ... guards in the Kraal and their Shambok [rawhide whip] .. had for the time being been left behind:

The Herero camps were finally abolished in 1908. Thereafter, the Herero were confined within a tangled web of legislation that sought to control every aspect of the lives of all black people living in German South West Africa (GSWA). Within the areas of German control, all Africans over the age of 8 were ordered to wear metal passes. These passes, which were embossed with imperial crown, magisterial district, and labor number, were used to facilitate German control of labor. In addition, Herero were prohibited from owning land and cattle, the two foundations of what had been a society based on pastoralism. ${ }^{10}$

\section{The 'Blue Book'}

At the outbreak of the First World War, South African forces under British command invaded GSWA and successfully defeated the much-vaunted German army. As the war progressed, it became clear that the victorious parties had no intention of allowing Germany to retain its colonies. To this end, from at least I9I5 onwards British colonial officials were instructed to gather materials which would strengthen the British Empire's claims to Germany's colonies. ${ }^{11}$ In Namibia, this task was made much easier by the existence of an extremely well-organized and detailed government archive which awaited the incoming military administration in Windhoek. It contained chillingly detailed accounts and reports on the manner in which GSWA settlers, and the colony's administration, had 
dealt with the country's original inhabitants. Apart from files dealing with the incarceration of Herero in concentration camps and their distribution among settlers and private companies, the archives also contained a series of files on the excesses of settlers who had flogged Herero and Nama ${ }^{12}$ workers. Glass-plate negatives detailed the torn and rotting backs of women flogged for alleged insubordination, and pages upon pages of court transcripts detailed the brutal lashing of laborers. ${ }^{13}$

The combination of dry testimony taken from the German archives in Windhoek, along with a series of painstakingly detailed statements given under oath by surviving Namibians, formed the basis of one of the most shocking documents of colonial history. The Report on the Natives of South West Africa and their of colonial history. The Report on the Natives of South West Africa and their Treatment by Germany (London, I9 I8), generally referred nature nature of German colonial rule in Namibia. It is beyond question that these materials effectively scuttled any attempts by Germany to retain control over its former colonies, and Namibia in particular. ${ }^{14}$ In Article Ir 9 of the Versailles Treaty Germany articular. ${ }^{14}$ In Article II 9 of the Versailles Treaty, Germany was declared unfit to govern colonies, Powers forced to renounce in favor of the Principal Allied and Associated Powers all her rights and titles over her oversea possessions.' In addition, under Article 22 of the new League of Nations charter, Namibia was held to be 'inhabited by peoples not yet able to stand by themselves under the strenuous conditions of the modern world, and thus was deemed a territory that could 'be best administered under the laws of the Mandatory [the Union of South Africa] as integral portions of its territory' Accordingly, Namibia was placed under the jurisdiction of South Africa (see du Pisani, I985: 76)

Though the 'Blue Book' is one of the primary documents detailing the injustices perpetrated against the Herero and Nama peoples of Namibia, it was not used to ensure that Herero would receive compensation. Instead, the 'Blue Book' served to ensure that Namibian territory would be granted to South Africa to administer as a mandated territory. Far from the Herero receiving their land back, the new South African administration forced them to settle on marginal lands in reserves established on the fringes of the Omaheke, the desert into which they had been driven in the past The new South African administration continued the policies initiated by its German predecessor. The lands previously occupied by the Herero continued to be reserved for white settlement, and in by the Herero World War I the South African white settlement, and in the years after World War I the South African administration pursued an aggressive policy and Sount from Angol and South Africa. In short, the injustices described with stark clarity in the 'Blue Book' were dismissed in the interests of white settler unity.

\section{White settler unity and the 'Blue Book'}

Nonetheless, the existence of the 'Blue Book' came to bedevil settler politics under the South African mandate. German settlers called for the 'Blue Book' to be banned and all extant copies destroyed. In I925, the first all-white election for a legislative assembly took place. Representatives of the German settler party, the Deutsche Bund in Südwestafrika, opposed settler parties allied to the Union of South Africa. Anxious to maintain a working relationship with the settler bloc in the legislative assembly, the South African administrator, A.J. Werth, acceded to settler demands for the abolition of the 'Blue Book.' Thus, in 1926, one Mr Strauch, a member of the legislative assembly, tabled a motion stating that the 'Blue Book' 'only has the meaning of a war-instrument ${ }^{15}$ and that the time has come to put this instrument out of operation and to impound and destroy all copies of this Blue Book, which may be found in the official records and in public libraries of this Territory.' ${ }^{16}$

The motion passed, and legislation came into effect in all territories administered by the Union of South Africa banning distribution of the 'Blue Book.' Copies were no longer made available to the public, were removed from libraries, and were destroyed. In the rest of the British Empire, copies of the 'Blue Book' were transferred to the Foreign Office. Even in wartime Britain as late as $194 \mathrm{I}$, in response to a request from the Ministry of Information, it was noted that "no copy may be issued without authority of the librarian. ${ }^{.17}$

Strauch, and his fellow members of the Deutscher Bund, consciously used the Herero genocide - or rather the recorded role of German settlers and soldiers in it - to put pressure on the South African administration. As Strauch noted, passing the motion he had proposed 'would .. remove one of the most serious obstacles to mutual trust and cooperation in this country [Namibia].' In his view, 'the honour of Germany had been attacked in the most public manner and it was right that the attack should be repudiated in an equally public fashion.... The defence of the honour of one's country was a solemn duty imposed upon all sons of that country.' The validity of Strauch's claims went unquestioned by the assembly, and certainly no Herero view of the events was allowed an airing. The subjective arguments of Strauch and his compatriots thus sought to obscure the past in the interest of preserving their own privileged position as settlers. The promise of peaceful cooperation with the German settler community was uppermost in the minds of South Africa's administrators. Strauch's claim that 'the Germans were ready and anxious to cooperate in the building up of South West but they could not do so 
fully until the stigma imposed by the publication of the Bluebook ... had been removed from their name' was considered a more powerful consideration than either historical veracity or the views of Namibia's African
inhabitants.

\section{Seeking to deny the past}

In the run-up to Namibian independence in 1990 , Brigitte Lau, a historian well known for her uncompromising stand against South African colonial rule in Namibia, published an article that shocked and surprised many of her colleagues. In her article, she stated: 'There is absolutely no evidence . that the Herero perished or were used on a large scale as "slave laborers" (Lau, 1989: S). Furthermore, Lau argued that the Vernichtungsbefehl issued by General Lothar von Trotha, commanding officer of German forces in Namibia at the time, 'was a successful attempt at psychological warfare never followed in deed' (Lau, I989: 5). In addition, Lau sought to problematize the term Vernichtung by arguing that it did not imply extermination. ${ }^{18}$ Finally, she argued that the basis for much of the allegations of genocide by German soldiers in Namibia, the 1904 'Report of the Treatment of Natives by Germany' (sic), was 'an English piece of war propaganda with no credibility whatsoever' (Lau, 1989: 5). ${ }^{19}$ Needless to say, Lau's article exploded like a bombshell among the small community of scholns specializing in Namibian history (Lau, I989: $4-8$ ). ${ }^{20}$

With hindsight, and on the basis of later conversations, it became clear that Lau wished to move the academic community away from what she saw as its unjust fascination with the Herero-German war. Instead, she argued, historians should concentrate on what she considered to be the more destructive colonial rule of South what she considered to be the genocide that Imperial Germany perpeth Africa in Namibia. Yet again, the negated and denied in the inany perpretrated upon the Herero was being less, Lau's article, recently interests of contemporary politics. Nevertheless, Lau's article, recently republished in German, continues to have website of the extend far beyond Namibian history. On the electronic (Traditional associationsverband ehemaliger Schutz und Überseetruppen organization that seeks to the former protectorate and overseas forces), an colonial armies, seeks to preserve and glorify the memory of Germany's Traditionsverband diu's article is predictably acclaimed..$^{21}$ In addition, the Herero?' (Restitution for teaders to 'Wiedergutmachung am der Volk der Trotha harboured any genocidal claims for reparations 22 (2)

\section{Michael Scott and Herero representations to the UN}

To the members of the white settler community, it may have looked as if the attempt to destroy and rewrite the past according to their own preferences had succeeded. For a number of years after 1926, nothing was heard of the Herero genocide. Within the territory, Herero had been forced to withdraw to the newly established Native reserves, where they refrained from directly articulating demands that related to the genocide (Gewald, 200I). This is not to say that the genocide was no longer of any importance to Herero society - far fromì it. Instead, Herero society turned in upon itself, seeking as far as possible to refrain from any interaction with the colonial state. References to the genocide perpetrated against the Herero surfaced from time to time in unexpected places, yet the subject was no longer part and parcel of the colonial discourse. ${ }^{23}$

In the aftermath of World War II, the South African government undertook steps to incorporate Namibia as the fifth province of the Union of South Africa. To this end, in 1946 a series of carefully structured meetings were held with the African population of the territory. As the newly formed United Nations had taken over from the League of Nations, Namibia, as a mandated territory, fell again under South African jurisdiction, with UN oversight. It was widely hoped that the colonially appointed and recognized leaders of Namibia's African populations would give their sanction to South Africa's plan to incorporate Namibia. However, this was not to be. The events of 1904-08 again became central to the concerns of settlers and the colonial administration with the arrival of the Rev. Michael Scott in Windhoek in $1947 .{ }^{24}$ In conjunction with Herero leaders, Scott used the atrocities perpetrated in the Herero genocide as a weapon against the incorporation of Namibia into South Africa. In the immediate aftermath of the Holocaust, the full extent of which was still only just beginning to be understood, an earlier genocide inflicted by the fathers of the Nazi perpetrators made for powerful political ammunition (Emmett, 1999: 253).

Throughout most of 1948 , Michael Scott lived in a tent along the Gammans river, just beyond the old location of Windhoek. Here he met and entertained township residents, many of whom had experienced the horrors of German rule firsthand (Troup, 1950: 173-80). Scott could not fail to have his attention drawn to the Herero genocide. Here, in a nutshell, Scott held, were the core inequities of colonial rule: a people had been driven off their land, slaughtered, banished to live in barren homelands - and still they held no rights. This concise presentation of history served to detail the injustice suffered by the Herero, at the 

hands not only of Imperial Germany, but of the mandated power, South
Africa.

An article entitled 'Michael Scott and the Hereros,' published in The New Statesman and Nation in 1949, aptly summarized Scott's view of Namibian history:

Then came the German colonists, hungry for land; and finally von Trotha, a general whom Hitler would have delighted to honour... In I904 he issued the 'Extermination Order.' All Hereros whether man, woman or child were to be killed. An orgy of looting, torture, and massacre followed. To read the records is exactly like reading the accounts of the obliteration of Poland, except that the Germans had not gas chambers then, but killed of Poland, except that the or burned sick old women in their huts. The tribes with their own hands, majority all but fifteen thousand by the Germans or died of thirst. ${ }^{25}$ of ninety thousand, were hacked to pieces

The mention of von Trotha's 'extermination order' clearly indicates that Scott had managed to gain access to a copy of the 'Blue Book.' Scott's history also made explicit the link between the horrors perpetrated by the Nazis and the activities of Imperial Germany's forces in Namibia, a link that continues to generate considerable academic interest. ${ }^{26}$ In addition, Scott explored how the South Africans had betrayed the Herero:

In the I9I 4 war, lured by British promises that native lands would be returned, the desert remnant trekked back. But in 19 I 8 they met not the British as the Mandatory Power, but the South Africans, who never for a moment considered giving them back their tribal lands. Some pastures were loft to considered settlers who remained. More went to the pastures were left to the German

Throughout 1948 and I949, in the face of constant harassment, Scott sought to bring conditions in Namibia to the attention of the world. Eventually, in November I949, the United Nations granted Scott an official hearing. Clearly, this did not stand him in good stead with South afficial officialdom. In the months following Scott's hearing, a campaign was initiated by the colonial authorities in Namibia, seeking to cast aspersions on Scott's statements. ${ }^{28}$ Vilified in the press, Scott continued to be supported by Herero, many of whom recalled the events of $1904-08$ to justify their faith in the reverend. One such Herero, who signed his letter 'A Native who has been deprived of his land from I904-1950,' noted: 'I want to emphasise that the information given by the Rev. Michael Scott at UNO is what actually happened in S.W.A. and was obtained from the best reliable sources' (Windhoek Advertiser, I950). Shortly after, Scott, already the victim of constant harassment, was declared a prohibited immigrant and prevented from ever returning to Namibia.

\section{Genocide and the establishment of nationalist parties}

In the Namibia of the I950s, the events of $1904-08$ continued to live in the memory of many Africans, and led directly to the establishment of the South West African National Union (SWANU) and the South West African Peoples Organization (SWAPO). Particularly within SWANU, which came to be dominated by Herero ideologues, the loss of land incurred in the Herero genocide proved a major mobilizing factor (Ngavirue, 1997: 214n; Emmett, I999: 283n). However, the political mobilization which had begun in earnest in Namibia in the years after World War II was brutally terminated by the shootings of December 1959. The shootings, by the South African authorities, were a response to African protests against the apartheid Group Areas Act (Dierks, I999: 124). In the aftermath of the killings, there was a substantial South African government clampdown on nationalist political organizations in Namibia. This resulted in a massive flight into exile by many of Namibia's most highly skilled and articulate Herero. ${ }^{29}$ It was in the context of these events that some Herero leaders who had remained in the territory sought to play down the conflict and tension engendered by the commemoration of the Herero genocide. Instead, they sought to pursue a policy of appeasement, and urged leaders of the German community to do the same. As Herero chief Hosea Kutako stated in response to German commemorations of the battle of Hamakari:

We do not want to cling to the past or to have old war grudges. Our aim is to forget the past and to look forward rather than backward and to have good relations with all sections of the population; but good relations cannot exist if some people try to remind us of the bad past. (Windhoek Advertiser, 1964a)

In contrast, younger Herero - men such as Clemens Kapuuo, Hosea Kutako's eventual successor - were far less conciliatory. When German settlers wished to commemorate the Herero-German war, Kapuuo reminded them of the terror wrought in the genocide, and its links to the Holocaust:

To our minds there is little difference between the extermination order of General von Trotha and the extermination of Jews by Adolf Hitler. The members of the Alte Kameraden are today a free people whereas the Hereros are not and are under a foreign Government which was elected partly by members of the Alte Kameraden. It is natural that the Hereros would be opposed to the celebration Kameraden. It is natural that the Hereros would be opposed to the celebration
of a battle which placed them under foreign domination up to this day. (Windhoek Advertiser, 1964b)

As might have been expected, Carl Schrader, spokesman for the Alte Kameraden, denied that the Herero had been 'exterminated.' 


\section{The Herero genocide and nationalist struggle}

Given the gravity of the Herero genocide, it seems remarkable that until the 1970s the only published account of the genocide in English was the 'Blue Book.' The revisionist academic theses of the German historians Horst Drechsler and Helmut Bley first appeared in German in 1966 and I968, in East and West Germany respectively. Bley's work, South West Africa under German Rule, 1894-1914, appeared in English in 1971, whilst Drechsler's 'Let us Die Fighting': The Struggle of the Herero and Nama against German Imperialism (1884-1915) was only published in English in I980. These two excellent studies were primarily concerned with a debate over the nature of German imperialism and the development of totalitarian societies. In particular, both books sought - and located - the roots of National Socialism in Germany's colonial past in Namibia. For both historians, the genocide committed against the inhabitants of Namibia between 1904 and 1908 foreshadowed later events in Western Europe between I939 and 1945. As Bley noted in the conclusion to his work: 'In SWA conditions crossed over into totalitarianism. This confirms, perhaps even reinforces, Hannah Arendt's contention that in African colonialism one may find the seeds of modern totalitarian rule' (Bley, 1971: 282, referring to Arendt, 1967: 185-222). These two books had a tremendous impact upon the manner in which the outside world perceived Namibia and South Africa's occupation of the territory.

In exile, the genocide against the Herero and Nama came to be one of the pillars of anti-colonial propaganda, deployed by those who wished to rid Namibia of its South African occupiers. Initially, this propaganda was based primarily on the works of Bley and Drechsler. The publication of To be Born a Nation by the SWAPO publicity bureau in London (SWAPO, I98 I) owed much to these two works.

In the early I980s, shortly after completing his Ph.D. in history at Oxford University, Peter Katjavivi (now vice-chancellor of the University of Namibia) became the highly articulate spokesman for SWAPO in London. Well-versed in Namibian history, Katjavivi, in condemning the attacks of South African forces, did not hesitate to liken them to those perpetrated by von Trotha seventy-five years earlier. The anti-colonial those gles of the Herero and Nama came years earlier. The anti-colonial struggles of the Herero and Nama came to be applied to all of Namibia, as if Ge nationalist struggle had begun with the wars undertaken by Imperial Germany against the two groups. The published version of Katjavivi's thesis, A History of Resistance in Namibia, clearly adopted this framework. In addition, it argued that Namibia's colonial governments were part of a continuum, with South African soldiers and police in the 1980 s merely continuing the work begun by the German colonial Schutztruppe in the
I 89 os (Katjavivi, 1984). ${ }^{30}$.

\section{Namibian independence, Herero genocide and} Herero unity

Whereas in the years leading up to Namibian independence (1990) the Herero genocide had been successfully appropriated by nationalist forces allied to SWAPO, immediately after Namibian independence the genocide became the preserve of Herero elites opposed to the new government. In the run-up to independence, Herero activists began seeking a formal apology from the German government for the events of 1904-08. In the late I980s, SWANU activists living in Germany approached the anti-apartheid movement in the Netherlands for assistance in bringing a case against the West German government. ${ }^{31}$

Since independence, the SWAPO government of Namibia has gone out of its way to ensure that Herero claims for reparation remain muted, or are nestled within the demands of the nation-state that SWAPO controls. The last time government ministers referred directly to the issue was during the visit of the then chancellor of Germany, Helmut Kohl, to Namibia in 1995. At the time, the Namibian foreign affairs minister, Theo-Ben Gurirab, noted in an interview that the injustices committed against the Namibian people by the former German colonial power would always remain a 'pestering [sic] sore.' The two countries needed to discuss war reparations 'at some stage,' but the issue was not a current priority for government, though Gurirab did add: 'We must have the courage and frankness to discuss this when the time is right' (Fild, 1995). The current Namibian government is well aware of the benefits that accrue to the state from continued close cooperation with Germany. No less than 46 per cent of the country's development budget is paid for by Germany (The Namibian, 1996). German military advisors and technicians are stationed in Namibia, where they teach and assist Namibian Defence Force personnel (Weidlich, 1995). In addition, direct flights from Germany bring europacking tourists, many of whom do not want to be troubled by thoughts of a terrible past. When the legal successors to the mighty German Kaiser visited Namibia and enjoyed the hospitality of its government, Chancellor Helmut Kohl and Bundes-President Herzog refused to meet Herero representatives, and were unwilling to offer an apology to the people of Namibia for what had happened in the past. Instead, Herzog referred to the war as 'a dark chapter in our bilateral relations' and made the extravagant claim that the massacres constituted 'a burden on the conscience of every German' (McNeil, 1998). At the time of writing, the government of Germany has made no official statement with regard to Herero claims. Nonetheless, while still in opposition, Germany's current governing parties did agree that what had occurred in Namibia constituted genocide (The Namibian, 1990). 


\section{Regaining the international stage}

It is in the context of the above events that on 22 August I999, Dr Kuaima Riaruako, the self-appointed paramount chief and king of all of the Herero, proclaimed that the 'Herero nation' as a whole had decided to approach the International Court of Justice (ICJ) in The Hague in order to lay a charge of genocide against the German state, calling for reparations for the slaughter and other atrocities inflicted on the Herero. At the time, Riaruako's statement ruffled a few feathers in Namibia itself. German diplomats in Windhoek emailed colleagues in Bonn/Berlin to look into the issue. Two days later, a clinically worded statement by a spokesperson of the World Court put everyone, with the exception of Riaruako, at ease: 'Only states may be parties in contentious cases before the ICJ and hence submit cases to it against other states. ${ }^{32}$

In the absence of a formal apology, the call for war reparations from the Federal Republic of Germany has become more vociferous Government inaction, the continued extensive presence of German tourists, settlers, businesses and farms, and continued marginalization of the Herero lend increasing legitimacy to the Herero claims. This new visibility was evident with the launch of two court cases in the US District of Columbia. With the support of Afro-American organizations, the 'Herero People' Reparations Corporation' (HPRC) was established as a corporation, in keeping with the laws of the District of Columbia, and the court cases were launched in its name. Three German companies, Deutsche Bank AG, Terex Corporation (Orenstein und Koppel), and Woermann Line (Deutsch Afrika Linien), were charged, along with the Federal Republic of Germany (in the person of its foreign minister, Joschka Fischer). The introductory paragraph of the charge reads as follows:

the Federal Republic of Germany ('Defendant' or 'Germany'), in a brutal alliance with German multi-national corporations, relentlessly pursued the enslavement and the genocidal destruction of the Herero Tribe in pursued the ennow Namibia. Foreshadowing with chilling Herero Tribe in Southwest Africa, of the European Holocaust only decades later precision the irredeemable horror commercial enterprise which decades later, the Defendant formed a German commercial enterprise which cold-bloodedly employed explicitly sanctioned extermination, the destruction of tribal culture and social organization, concentration camps, forced labor, medical experimentation and the exploitation of women and children in order to advance their common financial interests. ${ }^{3.3}$

\section{Conclusion}

At various stages in the past hundred years, the Herero genocide has leapt onto or fallen off the international stage. Every so often, a group of researchers, activists, or spokespeople stumbles upon this allegedly 'forgot- ten' genocide. Attempts are made to draw attention, once again, to the horrors of the past, whilst governments in power consistently attempt to sideline the issue or exploit it for their own ends. The 'Blue Book' thus was not used to ensure that Herero regained their lands or received compensation for the wrongs done to them. Instead, documentation of the genocide was used to prevent Germany from regaining control of its colonies, and ensure that these would instead be granted as mandated territories to the victorious allies. At later stages, in the interests of whitesettler unity, the 'Blue Book' was dismissed as a propaganda tract. The denial of the wrongs inflicted upon the Herero has continued to the present. In Namibia, a postcolonial government, anxious to retain the support of its German financial and trading partner, has sought to mute demands for war reparations, claiming that all Namibians, irrespective of ethnicity, suffered under colonial rule. However, German administration and hence genocide - never extended into northern Namibia, the area from which the current government derives its ethnic base of support.

The Federal Republic of Germany, as the legal successor to Imperial Germany, is responsible for what happened in the name of the Kaiser in Namibia. Genocide was perpetrated; thousands of people were put to work as forced laborers; thousands were subjected to all manner of abuse. People were robbed of their land, possessions, and livestock, and driven forever from their ancestral lands. It is hard to say what form recompense in this egregious case should take; but a simple apology would be a beginning.

\section{Notes}

This chapter builds upon a serıes of papers that the author presented in the course of $200 \mathrm{I}$ and 2002, of which the most notable are: 'Anticipating the Kaiser German soldiers and the Herero Genocide,' presented at 'Die koloniale Begegnung: Afrikanermnen in Deutschland (1880-1945): Deutsche in Afrika (1880-1918), Bad Godesberg, 5-8 September 200I; and 'Presenting the Past to Fight the Present: An Overview of the Manner in which the Herero Genocide Has Been Used for Political Purposes in the Course of the 20th Century, Afrika Studie Centrum, Leiden, 2001.

I. Throughout this chapter, I use the term 'Namibia' to refer to the territory that used to be known as German South West Africa.

2. Regarding the concept of self-fulfilling settler prophecies, see Marks, 1970.

3. Evangelical Lutheran Church in the Republic of Namibia (ELCRN),VI2 Karibib, 3. Evangelical Luth
author's translation.

author's translation.
4. See Bley, 1971: I $58-63$, for a discussion of the appointment of von Trotha. 5. See Pool, 1979: 219-40. Omaheke is the Otjiherero name for the sandveld area east of the Waterberg.

6. Namibian Natıonal Archives Windhoek (NNAW), ZBU D.1.a Band $3^{-4}$, leaf 
165. With thanks to Mr. W. Hillebrecht for finding it at such short notıce. Author's ranslation.

7. See Lau, 1989; Poewe, 1986; Spraul, I988; and Sudholt, I975.

ELCRN V 12, Missions Chronieken, Karibib ig06,

See also Berichte der Rhemischen Misstons-Cestlshaft, 1906, written by Missionary Elger of Herero was not mistreatmen military badquir structural, is indicated by a circular letter from military headquarters in Windhoek to the German officer commanding Karibib in late 1906. The letter noted: 'due to the mishandling of Herero prisoners, who act in late riers, it is advisable to recruit Ovambo labor as carriers.' NNAW, STR 191 . und 4. Kompagnie Karibib, Letter Windhuk 16/11/06.

9. ELCRN, V. 37, Missions Chronieken, Windhoek (Herero/Ovambo)

10. For an overview of German legislation regarding Africans in Nambia, see Zimmerer, 2001

II. Public Records Office (PRO) CO 537/I-17, Telegram from Mr Long, to Australia, New Zealand and South Africa, 4 January 1918, quoted in 'Memo for War Cabinet,' is October I9r 8.

12. Prior to the colonization of Namibra, Khoe speakers dominated southern and central Namibia. These people, the majority of whom were pastoralists, were derogatorily referred to in the past as Hottentots, and are presently known as Nama. In the wars of I904-08, the Nama lost virtually all of their land and known as Nama. In the wars of 1904-08, the Nama lost virtually all of their land and at least 30 per cent of their population. For a detailed, and as yet unsurpassed, overview of the German Nama
wars, see Drechsler, 1980: $176-217$.

I3. The glass plate negatives and files - in fact most of the original source material used to compile the 'Blue Book' - have been sought out by J. Silvester and J.-B. Gewald in the National Archives of Namibia. Sulvester and Gewald are currently preparing an edited and annotated edition of the 'Blue Book.'

14. Mayer (1967) provides a detalled and authoritative account of the Versalles Treaty negotiations. Carnegie Endowment for International Peace (1924) contans a complete text of the I9I9 Treaty.

15. Note the remarkable simularity in language used by Brigitte Lau (I989: 5 ), who stated, nearly seventy years later, that the 'Blue Book' was 'an English piece of war propaganda with no crediblity whatsoever.'

16. NNAW, ADM 225, Memorandum on the Blue Book, Annexure A. In addition, the administration was 'requested to make representations to the Union Government and to the British Government to have this Bluebook expunged from the official records of those Governments.' Furthermore, Strauch's motion requested that the Administration 'take into consideration the advisability of making representations to AdUnion Government and the British Government to of making representations to the Union Government and the Britsh Government to impound and destroy all copies of the Bluebook, which may be found in the public libraries in the respective Countries and with the official booksellers mentioned on the title-sheet of the Bluebook:

17. PRO F0371/26574 Minute, 20 June I94I

I8. Regarding the term Vernichten, Lau took her lead from Karla Poewe, who stated: "The use of the word "vernichten," which unknowledgeable people translate as extermin ation, in fact meant, in the usage of the times, breaking of mulitary national, ar extermin resistance' (Poewe, 1985: 60). For a response to this debate over meaning, or economic and Doerr, 1999 .

19. Research into the origins and compilation of the Report on the Natives of SouthWest Africa and their Treatment by Germany (London 1918), which is being edited and annotated for publication in 2002 by J.-B. Gewald and J. Silvester, indicates the report
was based on sound evidence.
20. A slightly reworked copy of this chapter was published in Heywood, 1995: 3952. Lau's article elicited responses from Randolph Vigne and Henning Melber (1990); Tilman Dedering (1993); and J.-B. Gewald (I994: 67-76). Lau's prece followed on a series of articles and books that have sought to deny the genocide, or, at the very least, called for a revision of histories dealing with the war. See, in this regard, Kühne, 1979; Nuhn, 1989; Poewe, 1986; Spraul, 1988; and Sudholt, I975.

2I. See www.traditionsverband.de/; author's translation.

22. Nordbruch is a German citzzen who, upon completing his German national service, moved to South Africa in 1986 . He continues to live in South Africa, yet travels widely lecturing to right-wing audiences. He is closely linked to the German National Partei Deutschland (NPD), being one of their foremost speech writers.

23. Thus, while searching for waterholes in the newly established Herero reserves in the eastern reaches of South West Africa, British administrators stumbled across the site of the German massacre of Herero at Ombakaha. See Gewald, I999: I82.

24. Scott is one of the more remarkable figures of southern African history. Having encountered Gandhi in India, he became actively involved in the anticolonial struggle, first in India and later in southern Africa. Initially Scott campaigned amongst the Indian community in Natal, and later became active in drawing attention to and improving the shameful living conditions in Bethel, one of Johannesburg's 'native locations.' Fol lowing his lobbying for Namibian independence, Scott was declared a prohibited immigrant and prevented from ever returning to Nambia and South Africa. In exile, he founded the Africa Bureau in London, and continued campaigning for Namibia's independence, even going so far as to drop his initual nonviolent approach. In 1958 while attending the All African People's Conference in Accra, Scott delivered a speech to the delegates on behalf of the Herero people living in Namibia who had been prevented from sending their own representatives. In his speech, Scott called for the creation of an African Freedom Army, saying: 'Africa needs such a freedom army urgently if it is to be saved from inhumanity.' Scott continues to be fondly remembered by many in Nambia. His activities brought the injustices of colonial rule in Namibia to the attention of the wider world. For an overview of this remarkable man's life, see Troup, I950.

25. NNAW, SWAA 198I, A $427 / 48$, Rev. M. Scott, typed copy of artucle that appeared in the New Statesman and Nation, 5 March 1949

26. Hannah Arendt was the first academic to alert the world to the linkages that exist between Germany's colonial past and the later development of the National Socialist state (see Arendt, 1967). The work of East and West German historians Horst Drechsler and Helmut Bley further developed this theme, and recently a new generation of historlans has once again taken it up. A sampling of some of the papers presented at the annual meeting of the African Studies Association in Houston, Texas, in Novembe 200 I shows the current prominence of the trend. They included Jan-Bart Gewald, 'Anticipating the Kaiser: German Soldiers and the Herero Genocide'; Jeff Gaydish, "'Die Lösung der Eingeborenenfrage": The Role of the Swakopmund Concentration Camp in the Development of German "Native Policy" in Southwest Africa'; and Casper Erischsen, 'Shark Island: Forgotten Concentration Camps and History in Colonial Namibra, 1904-1908.

27. See note 26

28. See, for example, NNAW, SWAA $198 \mathrm{I}$, A $_{427} 48$, M. Scott, draft letters of Bowker written to the Windhoek Advertiser and published I March r950.

29. These included Moses Katjiongua, Mburumba Kerina, Fanuel Kozonguizi, Zedekıa Ngavirue and many more. 
30. Katjavivi's 1984 thesis formed the basis for Katjavivı, 1988. Similar to Katjavivi's
work was that of fellow Herero exile Kaire Mbuende work was that of fellow Herero exile, Kaire Mbuende (1986).

3I. Author's personal observation regarding meetings held in Amsterdam in 1988
and 1989 .

32. Published accounts in The Namibian newspaper, 25 August 1999 and 8 September

33. Case papers in the possession of the author.

\section{References}

Arendt, H. (1967). Origins of totalitarianism. New York: Harcourt, Brace \& World. Berichte der Rheinischen Missions-Gesellschaft (BRMG) (I906). Wuppertal, Germany. Bley, H. (1971). South West Africa under German rule, 1894-1914. Evanston: Northwester University Press. Carnegie Endowment for International Peace (1924). The Treaties of Peace 1919-1923.
New York: Doubleday, Page.

Dedering, T. (I993). The German-Herero War of 1904: Revisionism of genocide or Dierks, K. (1999). Chronology of Namut Southern Afncan Studies 19, no. 1: 80-88.

Namibia. Windhoek: Namuban Scian history: From pre-historical times to independent

Damibia. Windhoek: Nambian Scientıfic Society. Drechsler, H. (1980). 'Let us die fighting': The struggle of the Herero and Nama against
German imperialism. London: Zed Books.

Du Pisani, A. (1985). South West Africa/Namibia: The politics of continuity and change. Emmett

Basel: P. Schlettwein Publishince and the roots of nationalism in Namibia, 1915-1966. Fild,

Fild, L. (1995). War reparations on govt agenda. The Namibian, 21 September.

Gewald, J.-B. (2001). 'We thought we would be free': Socio-cultural aspects of Herero history
in Namibia, 1915-1940. Cologne: Rüdiger Küppe Verlag. - (1999). Hevero Heroes: 4 gne: Rüdiger Küppe Verlag.

Oxford: James Currey. -

Itiniratio 19 ). Forced labour in the Onjembo: the Herero-German war of 1904-1908. Itinirario 19, no. I: 97-I04.

Heywood, A., ed. (1995). Histor of the Kasser. Botswana Notes and Records 26: 67-76. Jonassohn, K., and Doerr, Kistory and historography. Windhoek: Discourse/MSORP. sional paper. Montreal: K. (I999). The persistence of Naz1 Germany. MIGS occaKatjavivi, P. (1988). A history of resistance in Nor Genocide Studies.

Katjavivi, P. (1988). A history of resistance in Namibia. London: Zed Books. D.Phil. thesis, Oxford University.
(198) The rise of nationalsm in and its international dimensions.

Kühne, H. (x979). Die Ausrottungsfeldzüge der 'Kaserlıchen Schutztruppen in Afrika' und die sozialdemokratische Reichstagsfraktion. Militargeschichte I 8: 208-16.

2, April: 4-8

Times, 3 I May.
Ceil Jr. Its past on 1ts sleeve, tribe seeks Bonn's apology. New York Times, 31 May.

Marks, S. (1970). Reluctant rebellion: The 1906-8 disturbances in Natal. Oxford: Clarendon
Press.
Mayer, A.J. (1967). Politics and diplomacy of peacemaking: Containment and counterrevolution at Versailles, 1918-1919. London: Weidenfeld \& Nicolson.

Mbuende, K. (1986). Namibia: The broken shield. Lund: Liber.

The Namibian (1996). German visit is a 'total success.' 24 June.

- (1990). Major German parties agree on 'genocide.' 5 November.

Ngavirue, Z. (1997). Political parties and interest groups in South West Africa (Namibia): A study of a plural society. Basel: P. Schlettwein Publishing.

Nuhn, W. (1989). Sturm uber Sudwest: Der Hereroaufstande von 1904 - Ein dusteres Kapitel der deutschen kolonialen Vergangenheit Namibias. Koblenz: Bernhard Graefe Verlag.

Oermann, N.O. (1998). Mission, church and state relations in South West Africa under German rule (1884-I9I5). D.Phil, thesis, Oxford University.

Poewe, K. (1986). The Namibian Herero: $A$ history of their psychosocial disintegration and survival. Lewiston: Edwin Mellen Press.

Pool, G. (I991). Samuel Maharero. Windhoek: Gamsberg Macmillan.

- (1979). Die Herero-opstand 1904-1907. Pretoria: Haum.

Rust, C. (1905). Kneg und Frieden im Hererolande. Aufzeichnungen aus dem Kriegsjahre 1904. Berlin: Ernst Siegfried Mittier und Sohn.

Spraul, G. (I988). Der 'Völkermord' an den Herero: Untersuchungen zu einer neuen Kontinuitätsthese. Geschichte in Wissenschaft und Unterricht, December: 713-39.

Sudholt, G. (1975). Die deutsche Eingeborenenpolitik in Stidwestafrika. Von den Anfangen bis 1904. Hildesheim: Georg Olms Verlag.

SWAPO (198r). To be born a nation: The liberation struggle for Namibia. London: SWAPO Dept of Information and Publicity.

Troup, F (1950). In face of fear: Michael Scott's challenge to South Africa. London: Faber \& Faber.

Vigne, R. and Melber, H. (I990). Shark Island revisited. South African Review of Books, February-March, June-July, August-October.

von Estorff, L. (1979). Wanderingen und Kampfe in Südwestafrika, Ostafrika und Sudafrika: 1894-1910. Windhoek: John Meinert.

Weidlich, B. (1995). Helmut Bistri: Offizier und Gentleman. Allgemeine Zettung, I December.

Windhoek Advertiser (1964). 'Forget the past': Improve race relations, Kapuuo urges Kameraden. 7 August.

- (I964b). Hereros oppose Waterberg celebrations: Alter Kamerad denıes 'extermination,' 29 July.

(I950). Letter to the editor. I 8 March.

Zimmerer, J. (200I). Deutsche Herrschaft Über Afrikaner: Staatlicher Machtanspruch und Wirklichkeit im kolonialen Namibia. Hamburg: Lit Verlag. 